\title{
ANALYSIS OF ACCURACY CONTROL IMPROVEMENT METHODS OF ANTENNA SYSTEM MECHANISMS BASED ON STEWART PLATFORM
}

\section{Mykhailo Palamar; Yuriy Pasternak; Vira Pasternak; Stepan Mashtalyar; Sergiy Shevchuk}

\section{Ternopil Ivan Puluj National Technical University, Ternopil, Ukraine}

Summary. The purpose of this article is to identify and investigate the factors affecting the accuracy of the control mechanism. The analysis has shown that the accuracy of the structure control is also affected by the cardan connection, including those associated with its manufacturing error. The analysis made it possible to propose methods for improving the hexapod design and control accuracy.

Key words: hexapod, control systems, linear actuator, measurement error.

Problem statement. Low level of computing technologies preventing the problem of control solving has slowed down the active implementation of Stewart platform-based mechanisms into production and antenna equipment. Stewart platform (hexapod) (fig. 1) consists of fixed platform (1), pivot joints (2), joining six linear actuators (3) with moving platform (4). The study of spatial mechanisms of parallel kinematic structure control is very important for Stewart platform introduction into production and antenna equipment. Nevertheless, to achieve high dynamic characteristics one should determine the optimal geometrical packaging of the device, design the control system and provide it with the software implementing the adequate mathematical apparatus.

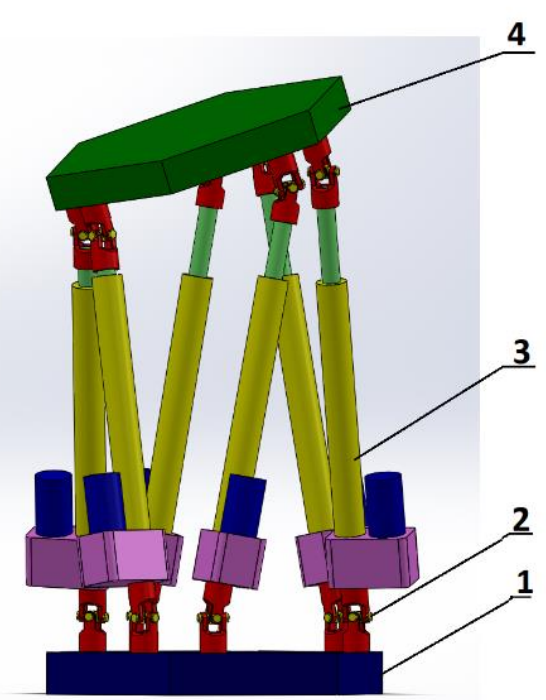

Figure 1. Stewart platform

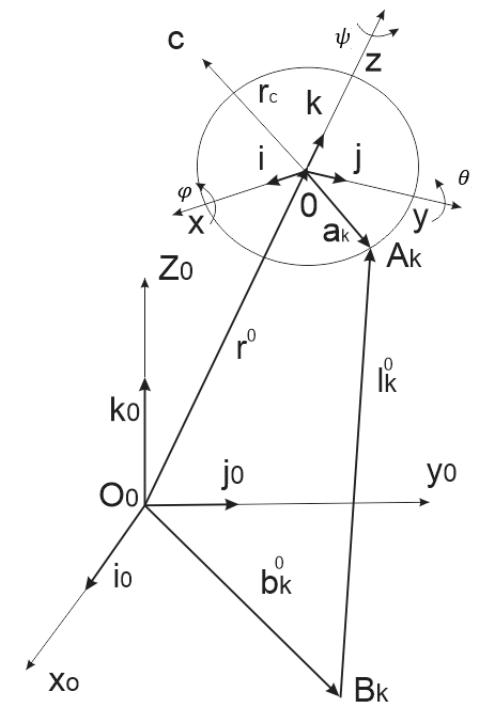

Figure 2. Kinematics of a Stewart platform 
Analysis of the known results of the study. The measurement of accuracy of parallel mechanisms positioning is possible only due to both the use of embedded into system sensors and external measurement devices as well.

As embedded sensors one can use:

- linear optical sensors for actuators mechanical elongation measurement,

- rotating optical sensors for actuators engine rotations measurement,

- force (moment) sensors for dynamic calibration.

The repeatable accuracy of the mechanism moving platform positioning relative to the fixed platform in the structure under consideration depends on the choice of control system and quality of hexapod actuators: linear actuators (LA), cardan joint.

Paper purpose. The task of the article under consideration is to analyze the publications dealing with finding the parameters making impact on the Stewart platform (hexapod) accuracy and determining the ways of their characteristics improvement.

Problem setting. Hexapod dynamics equation is of nonlinear character and depends on many indices which greatly complicate the mechanism control (fig.2). The method of control of a mechanism of parallel kinematic structure having six degrees of freeness (6 DOF) is considered to call the method of motion control in the working space. The above-mentioned method deals with the solution of the direct kinematic problem which assumes that the defined vector of actuator motion is $X$ and the vector of hexapod rod length $q$ has to be found. Many unknown values greatly complicate the solution of the direct kinematic problem and suggest nearly 40 options of solution. Control methods at inverse problem of kinematics solving when the actuator motion vector $X$ is found on the basis of vector of hexapod rod length $q$ value is called motion control in the space of generalized coordinate system [1,2].

The immediate problem of the Stewart platform is to find forces developed by the actuators to assure the platform defined motion [12]. Having summarized the coordinates in the center motion equation

$$
q=\left\{q_{i}\right\}=\left\{x_{0}, y_{0}, z_{0}, \varphi, \theta, \psi\right\}
$$

$q_{i}(t)$ is defined as a time function, then the equation looks like:

$$
\begin{gathered}
m\left(\ddot{r}^{0}+\dot{w}^{0} \times r_{c}^{0}+w^{0} \times\left(w^{0} \times r_{c}^{0}\right)\right)+m g k_{0}=F^{0}=\sum_{k=1}^{6} F_{k} e_{k t}^{0}, \\
r_{c}^{0}=P r_{c},
\end{gathered}
$$

where $\mathrm{m}$ - platform mass with the antenna mirror, $\mathrm{g}$ - gravitational acceleration, $r_{c}^{0}$ - radiusvector of the platform gravity center in the moving coordinate system, $\ddot{r}^{0}$-acceleration of the coordinate $\mathrm{O}, F_{k}$-force acting on the platform on the pin core side and moment equation of relative to the gravity center $\mathrm{C}$ in the moving coordinate system:

$$
\begin{gathered}
J_{c} \cdot \dot{w}+w \times\left(J_{c} \cdot w\right)=M=\sum_{\substack{k=1 \\
w \\
w}}^{6} F_{k}\left(a_{k}-r_{c}\right) \times e_{k t}, \quad e_{k t}=P^{T} \cdot e_{k t}^{0},
\end{gathered}
$$


where $J_{c}$ - inertia tenser relative to point $\mathrm{C}$, values $F^{0}$ and $\mathrm{M}$, main vector and main moment of forces acting on the platform on the actuator side are known and we are passing to the equation (3) to the projection on the fixed coordinate system, so we are writing the system (2) and (3) as:

$$
\sum_{k=1}^{6} F_{k} e_{k t}^{0}=F^{0}, \sum_{k=1}^{6} F_{k}\left(a_{k}^{0} \times e_{k t}^{0}\right)=M^{0}+r_{c}^{0} \times F^{0}=\dot{M}^{0}, M^{0}=P \cdot M
$$

As a matrix the system (4) looks like:

$$
\mathrm{A}^{\mathrm{T}} \cdot F=\mathrm{F}^{0}, \quad F=\left(F_{1} \ldots F_{6}\right)^{T}, \quad \mathrm{~F}^{0}=\left(F_{x}^{0}, F_{y}^{0}, F_{z}^{0}, \dot{M}_{x}^{0}, \dot{M}_{y}^{0}, \dot{M}_{z}^{0}\right)^{T}
$$

where matrix A:

$$
A \cdot V^{0}=i, \quad i=\left(i_{1} . . i_{6}\right)^{T},
$$

where matrix A consists of vectors taking into account the actuators lengthening and coordinates of their fixing to the platform, and symbol $\mathrm{T}$ denotes transposition.

At inverse problem solving taking into account the forces applied to the system by means of system of equations integration (2),(3) and (6) we obtain the motion of loaded Stewart platform.

Study outcomes. One of the key factors making impact on the antenna mirror position accuracy is technical and algorithmic basis of the control system. The analysis of structural schemes of control systems of parallel manipulators motion taking into account the statements of automatic control theory makes possible to determine the fact that without regard to their sphere of usage the mechanisms of parallel structure can be classified as multidimensional single-or two-circuit tracking systems with or without excitation correlation. As it has been proved in $[3,4]$ conventional tracking systems are restricting the possibilities of the defined trajectory accuracy increase due to the reduction of degree of freeness number at regulator structure choice as the regulator consists of one element of transfer function W.

The study of methods of motion control system development of mechanisms with parallel kinematics has proved that all of them aim at optimization of the set of autonomous PID regulators use in circuits due to their coefficients adjustment [13]. Though, such optimization restricts the ultimate limits of control accuracy which can be guaranteed under optimal situation conditions. To obtain the accurate displacement of the rod is possible only in the systems where the structure and parameters of excitation law and measurement errors will be chosen in the best way possible.

Besides, the study of methods of hexapod actuator motion control system development has proved that the mechanism division into separate channels according to the number of parallel kinematics rods is often proposed to simplify the model of control object and control system design procedures. In this case, the measurements errors and sensors dynamics, the use of ideal virtual models of parallel kinematics mechanisms to form the correlation signals have been neglected. Moreover, the real characteristics of the platform have been replaced by linearized ones and excitation actions - by axes mutual influence with their assessments. 
The dynamic control method based on control signals formation taking into account the manipulator dynamics equations has been widely used.

In this case the negative impact of non-linearity and crossed couplings can be overcome, the control quality can be increased, the control stability irrespective to a specific trajectory can be provided due to the more complex control. The factor restricting the mechanism control quality deals with the difficult analytical determination of a linearized model of dynamics. This difficulty is caused by the necessity of taking into account the drives control moments, friction forces, external forces and moments, centrifugal and Coriolis forces whose values haven't been known completely [7]:

- elastic deformations of links, hysteresis in mechanical joints, manufacturing and joints assembling errors;

- the defined moments of inertia and mechanism mass and load variables.

The object displacement accuracy at linear actuator (LA) independent control depends both on the Stewart platform-based mechanism (MPS) manufacturing errors of and on correct calculation of all kinematic parameters introduced into the mechanism control system as well to solve the inverse problem of kinematics. First of all, the initial link (moving platform with an object) displacement accuracy is influenced by the linear actuators operation accuracy. All these requirements to the accuracy of translational and rotational motion of the platform in $10 \mathrm{~s}$ of micrometers and 10s of angular seconds respectively results in the necessity of linear actuators rods displacement with accuracy up to micrometers units at the travel range up to $200 \mathrm{~mm}[8]$.

In hexapod design some hydraulic, pneumatic or electrical actuators are used. Electrical linear actuators (LA) and hydraulic actuators are the most widely spread among them which are usually used for big loadings, more than $2500 \mathrm{~kg}$ whereas pneumatic actuators are used for the mechanisms where speed and low load are important. The main disadvantage of hydraulic actuators is the possible oil leakage, whereas pneumatic actuators are difficult to be controlled under loading as the air is compressed but the length of the pneumatic actuator depends on its load.

To reach the highest accuracy of the drives control system one should close a linear actuator (LA) control loop by a feed-back on the output coordinate, i.e. linear position of its rod. The use of conventional linear position sensors allows the high accuracy of load displacement to be reached. The sensors of various operating principles can be used as linear position sensors. Potentiometer sensing elements provide simple reading of measuring information by the linear actuators (LA) control system (analogue-digital transformation is used as a rule), though they have a great disadvantage like low accuracy and reliability. Inductive and variable-capacitance transducers are extremely reliable and resistant to the external factors but they possess low accuracy. Interferometric sensors can measure the positioning as accurate as micrometers particles but they have a complex structure with expensive components and a special optical-electronic system of information processing. The above-mentioned characteristics have restricted the linear actuator design $[8,14,15]$.

According to the articles [5, 9-11], the own characteristics of mechanical transmission like ball-screw spindle (BSS) caused by their manufacturing errors are making the greatest impact on the linear actuator shaft displacement accuracy at continuous static loading.

A change in temperature of the ball-screw spindle (BSS) and other components of the mechanical transmission and connected with them the linear thermal expansion has also contributed to the displacement accuracy [4]. Thus, to provide the high accuracy of the rod 
displacement it is necessary to take into consideration two constituents: the own characteristics of the ball-screw spindle (BSS) and the linear thermal expansion of linear actuator (LA) mechanical transmission. In this case the linear actuator (LA) calibration is possible by the following technique: the real linear position of the rod for the whole performance range at the linear actuator (LA) fixed temperature value with necessary dimensional resolution is measured, then the rod displacement errors are calculated and discrete array of values (corrections) are formed. The corrections are recorded in the microprocessor module memory of the linear actuator (LA) control or in the upper-level control system and are further taken into consideration at linear displacement.

In the mechanism design the pivoting joints like universal joints or spherical (ball-andsocket) hinges have been used in most cases. Universal joints make possible larger angle range to be reached than spherical (ball-and-socket) hinges. Though spherical (ball-and-socket) hinges have small range of motion their advantages are fixed point of rotation, compact size and the component price. Control accuracy error will be caused by the pivoting joint manufacturing error and the system components arrangement in the whole.

Conclusions. The conducted analysis of factors making impact on the mechanism control quality has proved the difficulty in analytical determination of a dynamic model. Neglecting the dynamics of information smart sensors, noises accompanying the measurements and some manufacturing errors of joints has been found to be as the common disadvantage of the conventional control systems.

To improve the accuracy one should make some certain measurements and perform calibration if necessary. A set of additional high accurate sensors and devices which make possible to assess the moving platform position in space and other geometrical parameters of the system have been used in the measurements under discussion. One should also use a test signal approximate to the real one.

\section{References}

1. Dong Hwan Kim, Ji-Yoon Kang and Kyo-II Lee. Nonlinear Robust Control Design for a 6 DOF Parallel Robot. Received November 11, 1998.

2. Davliakos, I., and Papadopoulos, E. Model-based control of a 6-dof electrohydraulic StewartGough platform. Mechanism and Machine Theory. 2008. Vol. 43. No. 11. P. 1385-1400. DOI: https://doi.org/10.1016/j.mechmachtheory.2007.12.002

3. Aliyev F. A., Larin V. B., Naumenko K. I., Suntsev V. N. Optimizatsiya lineynykh invariantnykh vo vremeni sistem upravleniya: monografiya; In-t matematiki AN USSR. K.: Nauk. dumka,1978. P. 327. [In Russian].

4. Azarskov V. N., Blokhin L. N., Zhitetskiy L. S. Metodologiya konstruirovaniya optimal'nykh sistem stokhasticheskoy stabilizatsii: monografiya. K.: Knizhnoye izdatel'stvo NAU, 2006. P. 437.

5. Zhukov Yu. A., Korotkov E. B., Moroz A. V. Kinematic administration of space destination hexapod // Intellektualnye sistemy, upravlenie i mekhatronika - 2018. Materialy Vserossiiskoi nauchno-tekhnicheskoi konferentsii, 2018, p. 67-71. [In Russian].

6. Hamid D. Taghirad Parallel Robots. Mechanics and Control. CRC Press; 1 edition, by Taylor \& Francis Group. 2013. P. 533. DOI: https://doi.org/10.1201/b16096

7. Zozulya V. Overview of methods of construction of control systems of parallel kinematic structure based on stuart platform (hexapod). Automation of Technological and Business Processes, 11 (3), 23-31. URL: https://doi.org/10.15673/atbp.v11i3.1504.

8. Slobodzyan N. S. Otsenka tochnosti razomknutogo lineynogo privoda, dostizhimoy metodom kalibrovki i kompensatsii lineynogo teplovogo rasshireniya. Radiopromyishlennost. 2019. 29 (2). P. 54-61 DOI: https://doi.org/10.21778/2413-9599-2019-29-2-54-61

9. Zhukov Yu. A., Korotkov E. B., Moroz A. V. Simulation model hexapod control systems with linear stepper drives. Voprosy radioelektroniki. 2017. No. 7. P. 35-41. [In Russian]. 
10. Mishev G., Rupetsov V., Paskaleva K, Dishliev S. Factors affecting the accuracy of positioning of rectilinear motion systems. XV International Scientific Conference "RE \& IT - 2016". Conf. paper, 2016. P. 67-70.

11. Zhang Y., Pan S, Deng J. Methods for measuring and compensating ball screw error on multi-mode industrial CT scanning platform/ Proceedings of the 20165th International Conference on Measurement, Instrumentation and Automation, 2016. DOI: https://doi.org/10.2991/icmia-16.2016.144

12. Andrievskiy B. R., Arsepev D. G., Zegzhda S. A., Kazunin D. V., Kuznetsov N. V., Leonov G. A., Tovstik P. E., Tovstik T. P., Yushkov M. P. Dinamika platform Styuarta: monografiya. Vestnik SanktPeterburgskogo universiteta, 2017. URL: https://cyberleninka.ru/article/n/dinamika-platformy-styuarta.

13. Active disturbance rejection control of a parallel manipulator withself learning algorithm for a pulsating trajectory tracking task. A. Noshadi, M. Mailah Scie ntia Iranica B (2012) 19 (1), $132-141$. DOI: https://doi.org/10.1016/j.scient.2011.11.040

14. Palamar M., Nakonetchnyi Yu., Apostol Yu., Strembicky M., Mashtalyar S. Design source errors analysis in the angle measure devices to the precision. Scientific Journal of TNTU. Tern.: TNTU, 2018. Vol. 92. No. 4. P. 98-103. DOI: https://doi.org/10.33108/visnyk_tntu2018.04.098

15.Zelins'kyi I., Palamar M., Yavorska M. Optical system for control of antenna mirror shape. Scientific Journal of TNTU. Tern.: TNTU, 2019. Vol. 93. No. 1. P. 92-101. DOI: https://doi.org/10.33108/visnyk_tntu2019.01.092

\section{Список використаної літератури}

1. Dong Hwan Kim, Ji-Yoon Kang and Kyo-II Lee. Nonlinear Robust Control Design for a 6 DOF Parallel Robot. Received November 11, 1998.

2. Davliakos, I., and Papadopoulos, E. Model-based control of a 6-dof electrohydraulic StewartGough platform. Mechanism and Machine Theory. 2008. Vol. 43. No. 11. P. 1385-1400. DOI: https://doi.org/10.1016/j.mechmachtheory.2007.12.002

3. Алиев Б. В., Ларин В. Б., Науменко К. И. и др. Оптимизация линейных инвариантных во времени систем управления: монография. Наукова думка, 1978. С. 327.

4. Азарсков В. Н. и др. Методология конструирования оптимальных систем стохастической стабилизации. К.: Книжное издательство НАУ, 2006. 440 с. ISBN 966-598-325-3.

5. Жуков Ю. А., Коротков Е. Б., Мороз А. В. Кинематическое управление гексаподом космического назначения. Интеллектуальные системы, управление и мехатроника - 2018: материалы Всероссийской научно-технической конференции. 2018. С. 67-71.

6. Hamid D. Taghirad Parallel Robots. Mechanics and Control. CRC Press; 1 edition, by Taylor \& Francis Group. 2013. P. 533. DOI: https://doi.org/10.1201/b16096

7. Zozulya V. Overview of methods of construction of control systems of parallel kinematic structure based on stuart platform (hexapod). Automation of Technological and Business Processes, 11 (3), 23-31. URL: https://doi.org/10.15673/atbp.v11i3.1504.

8. Слободзян Н. С. Оценка точности разомкнутого линейного привода, достижимой методом калибровки и компенсации линейного теплового расширения. Радиопромышленность. 2019.29 (2). C. 54-61. DOI: https://doi.org/10.21778/2413-9599-2019-29-2-54-61

9. Жуков Ю. А., Коротков Е. Б., Мороз А. В. Имитационная модель цифровой системы управления гексаподом с линейными приводами на базе шаговых двигателей. Вопросы радиоэлектроники. 2017. № 7. C. 35-41.

10. Mishev G., Rupetsov V., Paskaleva K., Dishliev S. Factors affecting the accuracy of positioning of rectilinear motion systems. XV International Scientific Conference «RE \& IT - 2016». Conf. paper, 2016. P. 67-70.

11. Zhang Y., Pan S., Deng J. Methods for measuring and compensating ball screw error on multi-mode industrial CT scanning platform. Proceedings of the 20165th International Conference on Measurement, Instrumentation and Automation, 2016. DOI: https://doi.org/10.2991/icmia-16.2016.144

12. Андриевский Б. Р., Арсепьев Д. Г., Зегжда С. А., Казунин Д. В., Кузнецов Н. В., Леонов Г. А., Товстик П. Е., Товстик Т. П., Юшков М. П. Динамика платформ Стюарта: монография. Вестник Санкт-Петербургского университета, 2017. URL: https://cyberleninka.ru/article/n/dinamika-platformystyuarta. 
13. Active disturbance rejection control of a parallel manipulator withself learning algorithm for a pulsating trajectory tracking task. A. Noshadi, M. Mailah Scie ntia Iranica B (2012) 19 (1), $132-141$. DOI: https://doi.org/10.1016/j.scient.2011.11.040

14. Palamar M., Nakonetchnyi Yu., Apostol Yu., Strembicky M., Mashtalyar S. Design source errors analysis in the angle measure devices to the precision. Scientific Journal of TNTU. Tern.: TNTU, 2018. Vol. 92. No. 4. P. 98-103. DOI: https://doi.org/10.33108/visnyk_tntu2018.04.098

15. Zelins'kyi I., Palamar M., Yavorska M. Optical system for control of antenna mirror shape. Scientific Journal of TNTU. Tern.: TNTU, 2019. Vol. 93. No. 1. P. 92-101. DOI: https://doi.org/10.33108/visnyk_tntu2019.01.092

\title{
УДК 681.51, 621.3.07
}

\section{АНАЛІЗ МЕТОДІВ ПІДВИЩЕННЯ ТОЧНОСТІ КЕРУВАННЯ МЕХАНІЗМАМИ АНТЕННИХ СИСТЕМ НА ОСНОВІ ПЛАТФОРМИ СТЮАРТА}

\section{Михайло Паламар; Юрій Пастернак; Віра Пастернак; Степан Машталяр; Сергій Шевчук}

\author{
Тернопільський начіональний технічний університет імені Івана Пулюя, \\ Тернопіль, Україна
}

\begin{abstract}
Резюме. Мета даної статті полягає у вивченні факторів та чинників, які впливають на точність керування антенних систем на основі паралельних кінематичних ланок із статично невизначеними зв'язками. Проведено аналіз систем керування рухом дзеркала антени з опорно поворотним пристроєм на основі платформи Стюарта (гексапод). Визначено, щзо точність і повторюваність позиціювання рухомої платформи механізму щзодо його нерухомої основи в даній конструкції залежать від точності виконавчих елементів системи: лінійних приводів та карданного з'єднання. При цььому найбільший вплив на точність переміщення штока лінійного привода при постійному статичному навантаженні мають власні характеристики механічного передавання. Як показано в аналізі, проектування систем керування рухом робочого органу гексаподу поділяються на два основних напрямки: метод керування рухом у робочому просторі при розв'язуванні прямої задачі кінематики та керуванням рухом у просторі узагальненої координати при розв 'язуванні зворотної задачі кінематики. Як висвітлено в аналізі методів розроблення систем, керування гексаподу показує, щчо з метою спрощення моделі об'єкта керування та проектування системи керування часто пропонується поділ механізму на окремі автономні канали за кількістю итанг платформи Стюарта, нехтуючи похибками вимірювання й динамікою датчиків, використання ідеалізованих віртуальних моделей механізму паралельної кінематики для формування сигналів корекиії. Аналіз показав, щзо на точність керування конструкиї також впливає карданне з'єднання, зокрема похибки, пов'язані з його виготовленням та монтуванням. Одним із найважливіших етапів розроблення є необхідність підтвердження точності позиціонування системи. Проведений аналіз дозволив запропонувати методи покращення точності конструкиії та керування системою.
\end{abstract}

Ключові слова: гексапод, системи керування, лінійний актуатор, похибки вимірювання. 